\title{
The Liber de causis in Some Central European Quodlibets*
}

\author{
Iulia Székely \\ École nationale des chartes, Paris
}

This study presents the recent discovery of sixteen questions de quolibet, for the most part concerned principally with the analysis of theorems I, IV(V) and XII(XIII) of the Book of Causes, or with themes arising from the exegetical tradition surrounding this treatise. As a whole, these sixteen texts belong to a coherent, yet overlooked corpus of quodlibetal questions emerging from Central European universities, notably Prague and Erfurt, between 1400-1417.

These witnesses are important for the topic of the present volume for at least three reasons. First, they occurred at the end of the Middle Ages, in the newly-founded universities of the Germanic Holy Roman Empire, which are rarely examined in relation to the reception of the Book of Causes. Secondly, in broader terms quodlibetal questions from the 15th century differ from their better-known ancestors of the 13th century. One of their main characteristic is that their subjects where not spontaneously addressed by anyone (a quolibet) on any topic (de quolibet), but thoroughly prepared for many months prior to the event. Consequently, the decision to discuss specific topics-in this case, themes from the Book of Causes - is the result of a careful consideration. Thirdly, the Book of Causes was not among the works that the statues of the new universities included in the cursus of philosophy. Yet the masters studied and debated this text in large academic settings.

\footnotetext{
* I wish to thank Prof. Pascale Bourgain and Prof. Olga Weijers for their useful remarks on the Latin edition, and Dr. Evan King for the English translation. I am responsible for remaining errors. The present contribution has been presented in 2015 during the Parisian conference and then submitted for publication. I could not take into consideration the following article just published: O. Pavlíček, "Parisian and Prague Quodlibeta Compared: The Transfer of the Quodlibetal Disputation between the Faculties and Jerome of Prague's Struggle against the Thematic Limitations Imposed on the Faculty of Arts", in E. Jung (ed.), What is New in the New Universities?, Warszawa, Wydawnictwo IFiS PAN, 2018, p. 325-356.
} 
It is best to recall certain aspects of the character of medieval quodlibetal debate which serve to bring out more clearly the issues examined here. Disputation de quolibet appears in the first half of the 13th century (around 1230) in the Faculty of theology at the University of Paris. ${ }^{1}$ It derived from the disputatio ordinaria, a very popular oral exercise within the university which placed great importance on the formation of students. The quodlibet borrowed from this its division into two sessions (disputatio and determinatio) but, unlike the disputatio ordinaria that occurred weekly, a quodlibetal disputation took place twice a year, during Advent and Lent. Moreover, unlike other forms of university disputation, the quodlibet had no relation to teaching. We might instead call it a completely exceptional performance of the master, in which he had to respond to all questions posed by the public. Masters were not obliged to hold these disputations, but those who did could see it as a way of enhancing or establishing their reputation. They were supposed to be both highly competent in the subject matter and intellectually agile, since they had to confront a flurry of questions bearing on diverse and at times daring topics. ${ }^{2}$ On the day when this ceremony would take place, students were given dispensation from their courses to assist at the debate. The event would be open to all: students, masters, educated persons not part of the university, civil and ecclesiastical authorities - even the bishop at times would be present. It is equally important to recall the proceedings of the dispute (in two stages) in order better to understand its subsequent transformations.

The disputatio stands as the first session of the event, where the master would respond to questions posed to him by any person from the audience (a quolibet) and concerning any theme whatsoever (de quolibet). During this session, one or several bachelors would play the role of respondens (a requirement for the baccalarii formati) and give provisional responses to the various questions. We also note the presence of one (or several) opponens, who offered objections and refuted arguments. Generally, the master would intervene only rarely in this first stage. The second phase, the determinatio, occurred several days later. Over the interim, the master reorganised all the material of the preceding session and prepared his definitive response. He would present the questions in a logical order, summarise at various lengths the arguments

1 Wippel 1982, p. 157, n. 1. Glorieux, 1925, p. 11-55.

2 Glorieux 1935, p. 13: “(...) l' on comprend sans peine pourquoi on se pressait aux Quodlibets comme à un spectacle toujours nouveau et toujours attrayant. Nul ne savait quelles péripéties s'y dérouleraient, ni au prix de combien d' efforts le maître sortirait victorieux". 
presented during the discussion and give his own solution. In most cases, the master also had the obligation of preparing an official version of the dispute for publication.

Disputation de quolibet has long been considered to be closely related to the Faculty of theology in Paris since, on the one hand, around $80 \%$ of extant texts witness to this setting and, on the other hand, as Olga Weijers has noted, "it had no real equivalent in the Faculty of arts". ${ }^{3}$ Indeed, we have only a few sources in manuscript of disputations de quolibet held in the Faculty of arts in Paris in the 13th century. It seems they took place once a year, in winter, in the church of Saint Julien le Pauvre. ${ }^{4}$ The few texts that have come down to us tell us nothing about their proceedings, but allow us to see that these quodlibeta, above all, treated questions of natural philosophy. Their argumentation seems to have been very different from that of the theologians and consists in very brief responses. Around 1320, the prestige of quodlibets fades considerable in Paris.

The situation is very different in the Germanic Holy Roman Empire, where new universities were being founded from 1348 . These solemn events were integrated into academic life around the end of the 14th century and the beginning of the 15th century, as indicated both by university statutes and by the texts themselves that have been conserved. ${ }^{5}$ The disputes took place once a year and constituted a large-scale event which, according to Pavel Spunar, represented "the visiting card", as it were, of the university organising it. ${ }^{6}$ The new form of the quodlibet is, however, very different in comparison to its Parisian roots from the $13^{\text {th }}$ century.

First of all, the dispute de quolibet was no longer a speciality of the Faculty of theology, but became a distinguishing feature of the Faculty of arts. Indeed, the Faculties of medicine, law and theology were excluded from the organisation of these events. ${ }^{7}$ Secondly, the proceedings of the ceremony underwent a change, as the various university statutes attest. Generally speaking, these statutes provide the same description, with some minor differences. ${ }^{8}$ In the present

3 Weijers 2009, p. 99.

4 Glorieux 1935, p. 19.

5 The oldest statute describing the proceedings of a disputation de quolibet comes from the Faculty of Arts in Prague. It dates from 29 October 1379, during the deanship of Johannes de Wylre, alias de Gulch. Liber decanorum facultatis philosophicae Universitatis Pragensis 18301832, p. 101-102.

6 Spunar 1997, p. 474.

7 As we read in the statutes of the Faculty of Arts of Erfurt: Item pro quodlibetario deputetur magister in artibus non licentiatus in alia facultate (...). Weissenborn 1884, p. 140, §93.

8 Until this point I have studied the proceedings of disputations de quolibet in the statutes of the Faculties of Arts in Prague, Erfurt, Vienna, Heidelberg and Leipzig. Only the statutes of Leipzig give no instruction on the dispute de quolibet; we find solely a reference concerning 
study, I shall concentrate on the universities of Prague and Erfurt, from which the questions de quolibet analysing topics based on propositions from De causis properly speaking have emerged.

The regulations of the statutes relative to disputations de quolibet date from 1379 and 1391 for Prague, ${ }^{9}$ and from 1412 for Erfurt. ${ }^{10}$ The events took place once a year: in Prague on 3 January; and in Erfurt, on the feria following the feast of Saint Bartholomew (after 24 August). Several months before the disputation, a quodlibetarius (who, in Prague, was called magister disputans, disputaturus or presidens) was elected to prepare and preside over it. He had to be a regent master, but did not have to meet any requirements of seniority. He only had to accept the role willingly. The ceremony began with a prayer or a brief inaugural address, followed by the examination of the questio principalis. Then came the replies from the masters, with priority given to the rector of the University and the dean of the Faculty of arts, followed by the masters of arts according to academic seniority.

The quodlibetarius was entrusted with the task of preparing both the principal question (questio principalis) and the questions for the masters. The questio designated as principalis was prepared before the ceremony by the quodlibetarius who would present his arguments. First, a bachelor named as respondens would give provisory arguments, then the question would be scrutinised by all those who held a university degree. In Prague, the theme of the questio principalis was always on the first principle of the cosmos, while in Erfurt it could develop a topic pertaining to natural philosophy, ethics or metaphysics. Then came the questions posed to other masters. Unlike quodlibets in the West in the $13^{\text {th }}$ century, where questions were spontaneously posed to masters by the public, in the quodlibets of central Europe in the 14th and 15th centuries, the master (i.e. the quodlibetarius) posed questions to his colleagues, that is, to the other masters involved in the event. The quodlibetarius composed these questions well in advance of the ceremony and passed them over to each master several weeks before the event, so that they would be able properly to prepare themselves. We do not know if these questions were given along with supporting arguments (pro and contra), or if they consisted only in the dec-

the recommendation made to regent masters to attend the disputes regularly. Despite the paucity of information, these disputations undoubtedly took place in Leipzig and are transmitted in many manuscripts. decanorum facultatis philosophicae Universitatis Pragensis 1830-1832, p. 64-65, p. 101-102. The statutes of the Faculty of Arts in Erfurt concerning quodlibets are edited in Weissenborn 1884, p. 139-140. 
laration of the question itself. In the case of Prague, however, it is certain that the presidens of the disputation developed, in writing, a complex setting for the dispute which he would direct: his inaugural and closing addresses, his principal question and the questions intended for the masters, accompanied by his own arguments (for and against) that he used to confront the dialectical discussions ensuing with each of the respondents. In Erfurt, the questions assigned to the participants by the quodlibetarius had to be restricted to each master's area of specialisation. In both cases, the ceremony could last for many days, until every master had discussed the question addressed to them. At the end of this "verbal duels", the quodlibetarius would usually offer a closing address and would thank the audience.

The evolution of quodlibetal disputation is striking. With the increase in pomp and circumstance, the element of spontaneity is replaced by lengthy preparations. Disputatio de quolibet became a sort of sumptuous event peculiar to the philosophers. The various manuscript witnesses which transmit these quodlibets exist in many forms: the disputed questions are conserved by themselves, or in collections of questions de quolibet, in the form of reportationes (rarely) or in manuals of quodlibetarii. The latter are precious documents that relate the preparations preceding the quodlibetal dispute by the master responsible for their direction. At the present state of research, only manuals from Prague are known. In their most complete form, they include the following elements: the preliminary address, the principal question (debated by the quodlibetarius), the questions prepared to be addressed to the masters, accompanied by paragraphs contra concedentem et contra negantem and, finally, a closing address. It is worth bearing in mind that these paragraphs contra concedentem and contra negantem do not reflect the content of the dispute as it actually took place, but rather the arguments prepared by the quodlibetarius in order to facilitate the discussion that he must carry out with each participant. So even if the disputation as such cannot be reconstructed from these manuals, through them one can at least have some insight into the doctrinal interests of the university, into the thought of the master-quodlibetarius and into the authorities upon which his arguments depend.

Most of the extant quodlibetal questions coming from central European universities are still unedited. No systematic study has examined them, with one notable exception being the monograph of Jiři Kejř (written in Czech), ${ }^{11}$ who provides a list of questions debated in Prague between 1394 and 1417. Thirteen of the sixteen questions considered in the present study come from the man-

\footnotetext{
$11 \quad$ Keǰ̌ 1971.
} 
uals of quodlibetarii in Prague (three of which are conserved in Prague and one in Leipzig); the remaining three were discussed in disputations de quolibet in Erfurt. In the case of the Prague manuals, the names of the masters who authored the manuals are known, as are the years of the disputes.

\section{The Liber de causis in Quodlibetal Disputations}

2.1

\section{The University of Erfurt}

2.1.1 The questio principalis of Henry of Geismar ${ }^{12}$

Henry of Geismar pursued his studies in Prague at the end of the 14th century, matriculating as a bachelor in the Faculty of arts. He became rector in Erfurt in 1412 and participated in the reform of the university's statutes. ${ }^{13}$ In 1414, he was elected quodlibetarius to organise the disputation in the same year. At the present state of research on the University of Erfurt, his quodlibet is the oldest known to us. ${ }^{14}$ I have co-edited the quodlibet by Henry of Geismar, in another publication. ${ }^{15}$

Of the disputation organised by Henry, we know only the principal question that he would have prepared in advance and disputed during the ceremony. It is an interpretation of theorem I of the Liber de causis. The doctrinal discussion developed by Henry is quite unique for the $15^{\text {th }}$ century, inasmuch as it returns to the exegetical tradition prior to the commentary of Thomas Aquinas, notably to the text attributed by scholars to Adam of Bocfeld, from which Henry copies several passages. ${ }^{16}$ Furthermore, he utilises the terminology of causality and influx from Roger Bacon and pseudo-Henry of Ghent, while passing over Albert the Great's doctrine of fluxus. He never mentions Proclus and makes no reference to the separate substances. For his theory of causality, Henry adopts an Aristotelian model, offering an interpretation of the first theorem of the Liber de causis which compares causes of the same genus (the first formal cause flows forth more abundantly than the secondary formal cause into the same

\footnotetext{
12 This question is conserved in two manuscripts: Erfurt, Universitäts- und Forschungsbibliothek Erfurt/Gotha, CA $4^{\circ} 236$, f. $29^{\mathrm{r}_{-}} 33^{\mathrm{v}}$ and Uppsala, Universitetsbibliotek c 639, f. $111^{\mathrm{r}}-$ $114^{\mathrm{r}}$.

13 Kleineidam 1981, p. 388. The statutes of the Faculty of Philosophy (including its instructions for the disputatio de quolibet) are revised on 14 September 1412, during the deanship of Johannes Lorber de Cassel. Weissenborn 1884, p. 123.

$14 \quad$ Kleineidam 1981 p. 82.

15 Calma, Székely 2016, p. 181-223.

16 Calma, Székely 2016, 196-199. On the commentary by Adam of Bocfeld see Calma 2018.
} 
effect) and the causes of different genera (the formal cause flows forth more abundantly than the material cause, and the final cause more than the efficient cause). In the first case, he invalidates the first proposition of the De causis by maintaining that the secondary cause influences more than the first, but in the second case he confirms the theorem, holding that the final cause has greater influence than the others.

\subsubsection{A Disputed Question of Peter Steinbecke}

Peter Steinbecke was master of the Faculty of arts in Erfurt and a colleague of Henry of Geismar. In 1415, he held the position of rector at the University of Erfurt as Master of arts and as a formed bachelor in theology. His quodlibetal questio is conserved in the same Erfurt codex as that of master Henry. ${ }^{17}$ It is attributed to him, according to a note in the manuscript, in 1417, by a quodlibetarius whose name remains unknown. It is therefore not a questio principalis, but one of the questions prepared in advance by the master who presided over the disputation. ${ }^{18}$ The proposed topic is: Utrum quelibet intelligentia citra primam plena formis existens suam essentiam intelligat et substantias materiales. This question is composed of a suppositum concerning theorem $\operatorname{Ix}(\mathrm{x})$ of the De causis: Omnis intelligentia plena est formis; and a quesitum on theorem $\mathrm{XII}(\mathrm{XIII})$ : Omnis intelligentia intelligit essentiam suam. The master's solution is divided into three articuli, composed of conclusions and corollaries. The solution given by Peter Steinbecke is connected with the doctrine of the De causis, of which he cites five propositions: $\mathrm{V}(\mathrm{VI}), \mathrm{VI}(\mathrm{VII}), \mathrm{VII}(\mathrm{VIII}), \mathrm{IX}(\mathrm{X})$ and XII(XIII). Among the authors evoked, we find Aristotle's Metaphysics (books XI and XII) and De anima (book III) and the Metaphysics of Algazel.

When setting out the plan of his disputation, Peter indicates that he will leave aside an argument referring to the essence of the first cause since another master will discuss this topic: (...) tertio pretermissa, scilicet de essentia prime cause, cum de hoc, sicut informatus sum, unus magistrorum meorum reverendorum habeat determinare (Ms Erfurt, Universitäts- und Forschungsbibliothek Erfurt/Gotha, CA $4^{\circ} 236$, f. $47^{\mathrm{v}}$ ).

\subsubsection{An Anonymous Disputed Question}

An anonymous question, which was likely disputed in Erfurt also in the 1420s, is conserved in the same manuscript from Erfurt (Erfurt, Universitäts- und

17 MS Erfurt, Universitäts- und Forschungsbibliothek Erfurt/Gotha, CA $4^{\circ} 236$, f. $47^{\mathrm{v}}-49^{\mathrm{r}}$.

18 MS Erfurt, Universitäts- und Forschungsbibliothek Erfurt/Gotha, CA $4^{\circ} 236$, f. $47^{\mathrm{v}}$ : Questio pro quotlibeto magistri Petri Steinecke. Anno XVII [septemdecimo]. 
Forschungsbibliothek Erfurt/Gotha, CA $4^{\circ}{ }^{236}$ ) as the texts of Henry of Geismar and Peter Steinbecke. ${ }^{19}$ We have no precise indication as to whether it is a questio principalis or a question posed to a master in the faculty at Erfurt. The text presents a discussion on a subject taken from theorem XII(XIII) of the Liber de causis: Utrum quelibet intelligentia intelligat se et quamlibet aliam $a$ se. The response is structured in three articuli that aim to demonstrate, in order, that the intelligence knows by intuition and not by abstraction, that the intelligence knows itself and, finally, that it can also know an intelligence other than itself. These three articles each contain several conclusions and corollaries. The authors cited by the anonymous are the Liber de causis with theorem VII(VIII) (Omnis intelligentia scit quod est supra se et quodest sub se), book XII of Aristotle's Metaphysics, books II and III of the De anima, the Commentary on the Metaphysics by Averroes (book XII), regarding the possibility of the highest intelligence to know the first cause, making the distinction between agens per intellectum and agens a natura.

One codicological aspect should be noted here: the question, written on a bifolio, was integrated into the codex without any relation to the preceding or subsequent text. The bifolio was visibly folded twice and, on the verso of the final folio, two identical notes appear in German: Mit Heil [with greetings]. This likely is a letter. One might suppose that the master who disputed the question (or his secretary) sent it to an addressee whose name remains unknown. Was it sent to the scribe preparing the publication of the disputed question? Or was it sent before the event in order to prepare the disputed question? It is hard to tell. The letter, once unfolded, was inserted into the manuscript but previously circulated independently of it, since the verso of the final folio is dirty.

\section{$2.2 \quad$ The University of Prague}

\subsubsection{A Question from the Manual de Quolibet of Simon of Tišnov}

Simon of Tišnov became master of the Faculty of arts in Prague in 1398 and, in 1411, he held the post of rector in the university. That same year the ceremony de quolibet presided by Jan Hus took place. ${ }^{20}$ Simon was elected quodlibetarius to preside over the dispute on 3 January 1414 , but it could not take place, as indicated in an article issued from the deliberations of 8 January 1414, mentioning the rector's decision to delay the debate to follow the feast of Saint George [23 April 1414]. Yet again, however, it did not take place. ${ }^{21}$ On 23June 1414, Simon

\footnotetext{
19 Ms Erfurt, Universitäts- und Forschungsbibliothek Erfurt/Gotha, CA $4^{\circ} 236$, f. $35^{\mathrm{r}}-36^{\mathrm{v}}$.

20 The dispute de quolibet presided by Hus is edited in Ryba 2006 (second edition).

21 Liber decanorum facultatis philosophicae Universitatis Pragensis, 1830-1832, p. 424, 426, 428 .
} 
of Tišnov was elected once more quodlibetarius (for the dispute on 3 January 1415) but, for unknown reasons, the ceremony was postponed again. On 23 June 1415, the masters decided to keep Simon as the organiser of the quodlibet in 1416 , and it was then that the debate finally took place. At that time, Simon was still an avid follower of the ideas of Jan Hus, who died at the stake one year earlier, on 6 July 1415. In 1419 Simon changed his views and became a severe critic of the Hussites. The question that we present here and edit in the appendix of the present contribution is taken from his manual as quodlibetarius, but we do not know the name of the master to whom Simon posed it.

The question planned by master Simon was composed of a suppositum (Utrum sicut nulla secundarum causarum potest effectum creare prima causa ipsum non concausante ...) and a quesitum (... ita prima causa non cuiuslibet cause secunde vicem supplere potest in causando). The framework typical of the Prague manuals of the quodlibetarii is present, with paragraphs contra concedentem and contra negantem. Here, in fact, one finds four paragraphs: against and for the suppositum and against and for the quesitum respectively. These paragraphs contain several short arguments.

One passage in particular is worthy of our attention here. It is found in the paragraph against the suppositum questionis - in this case, against the idea that no secondary cause can create an effect without the participation of the primary case. To criticise this position, Simon tacitly copies a thesis which has its remote roots in question 2 of Siger of Brabant's commentary on the De causis. Siger refers here to a polemic made against the moderni by Averroes in his Commentary on the Metaphysics (book IX). Averroes criticises, in all likelihood, the Ash'arites, who held the view that the first cause can produce all things immediately. Yet Siger would not have known the details of the polemic against the Ash'arites. He instead uses this passage to develop a critique of Thomas Aquinas. ${ }^{22}$ Indeed, in his Sentences commentary, Aquinas explicitly cites theorem I of the Liber to develop a philosophical explanation of the miracle of the Eucharist. The Dominican explains that, just as the first cause does not cease influencing an effect when a secondary cause withdraws its influence, so God is able to make accidents subsist without their substance. By redefining the relation between substance and accidents, Thomas specifies that the latter are able to subsist in quantity. ${ }^{23}$ Siger attacks this position, criticising Thomas for trying to explain with philosophical language phenomena which do not belong to the natural order of things, and instead affirms the view that the first cause

22 Imbach 1996a, p. 317-318.

23 Imbach 1996b, p. 312-313; 316-320. 
can never dispense with the activity of secondary causes. According to Siger, if the first cause were in fact to intervene directly, as the opponents combatted by Averroes in his commentary on book IX of the Metaphysics maintain, the existence of secondary causes would have no meaning, as they would be deprived of their proper operations. ${ }^{24}$ It is certainly this discussion, with the reference to Averroes and the vocabulary of Siger, which is taken up in the question by Tišnov:

$\begin{array}{lll}\text { Averroes, Super Metaphysi- } & \text { Siger of Brabant, Quaestiones } & \text { Simon of Tišnov, Questio de } \\ \text { cam, IX, comm. 7, p. } 38 & \text { super librum de causis, q. 2, } & \text { quolibet, Praha, Knihovna } \\ & \text { p. } 40 & \text { Narodniho muzea V C 42, } \\ & & \text { f. } 102^{v}\end{array}$

Moderni autem ponunt unum

agens omnia entia sine medio, scilicet deum. Et contingit istis,

ut nullum ens habeat

actionem

propriam naturaliter. Et cum entia non habuerint actiones proprias, non habebunt essentias proprias. Actiones enim non diversantur nisi per essentias diversas. Et ista opinio est valde extranea a natura

hominis. Et qui recipiunt hoc, non habent cerebrum habile naturaliter ad bonum.
Quidam homines vulgares et populares opinati sunt, sicut recitat AVERROES SUPER NONO METAPHYSICAE quod CAUSA PRIMA omnia faceret immediate, quod esset agere causam primariam sine SECUNDARIA. Et hi, sicut dicit, non habentes cerebrum ad bonum naturale TOLLUNT AB ENTIBUS proprias operationes; quare et essentia et virtutes. Et secundum sic dicentes entia causata omnia essent frustra.
Confirmatur: ymmo sequitur quod nulla foret operatio propria alicuius CAUSE SECUNDE, quod est falsum et contra COMMENTATOREM IX METAPHISICE dicentem: unumquodque entium utitur accione sibi propria. Et ibidem dicit: qui ponunt unum agens esse quod agit omnia et TOLLUNT A REBUS suas proprias actiones non habent cerebrum aptum natum ad bonum. Et consequentia patet, quia quelibet operatio cum dependet a PRIMA CAUSA, prime cause est attribuenda, ergo non erit proprie propria secunde cause etc.

24 Marlasca 1972, p. 40. 
One can recognise Siger's expression in the text from Simon: causa primaria-causa secundaria, where Averroes speaks of Deus, medium; like Siger, Simon uses tollere ab entibus/rebus, an explication absent in the text of Averroes. Despite these similarities, Simon may not rely directly on Siger's text, but rather on an exegetical tradition. Indeed, recent studies ${ }^{25}$ have brought to light four commentaries on the Liber, from the end of the 13th and the beginning of the 14th centuries, which use this same background, with the same arguments and reference to Averroes as Siger: a commentary by John of Mallinges, the commentary of an anonymous Parisian master, the text of which is conserved in Erfurt, a commentary attributed to Radulphus Brito, and a short, anonymous Averroist commentary preserved in a manuscript in the Bibliothèque nationale de France.

In the paragraph intended to weaken the argument that the first cause cannot substitute itself for the function of the secondary cause in the causal order, Simon introduces a theological thesis. One has the impression that he refers to the above-mentioned position of Thomas Aquinas (IV Sent. d. 12, q. 1, art. 1):

Confirmatur theologice: prima causa est causa simpliciter omnipotens et mirabilissima in causando quemcumque effectum ad extra. Igitur sua potentia et mirabilissima causantia vicem cuiuslibet cause secunde supplere poterit in causando saltem mirabiliter et miraculose.

Ms Praha, Knihovna Narodniho muzea V C 42, f. $102^{\mathrm{v}}$

This question constituted of a suppositum (Utrum sicut una secundarum causarum potest effectum causare prima causa ipsum non concausante) and a quesitum (ita prima causa non cuiuslibet cause secunde vicem supplere potest in causando), can be discerned in two questions from the manual of Mathias of Knin, redacted seven years earlier ${ }^{26}$ (Utrum prima causa vicem cuiuscumque cause secunde suplere poterit in causando, et Utrum secunde cause possunt suos effectus causare prima causa non concausante).

\section{3} Conclusions

The themes treated in these quodlibeta allow us partially to reconstitute extracurricular philosophical disputations of the new universities. Although there

25 See in the present volume the contribution of D. Calma.

26 The manual of the quodlibet presided by Mathias of Knin, dating from 1409, is conserved in the Library of the Metropolitan Chapter of Prague, under the shelf L 45 . 
is a change in the status of the quodlibet into the lands of the Germanic Holy Roman Empire, with a notable transfer from the Faculty of theology in the 13th century to the Faculty of arts in the 15th century, it is worth observing that these questions also touched theological topics. Indeed, the quodlibet was an occasion to listen to the master of arts discuss themes that would have been of interest to all the members of the university. In this context it is remarkable that, between 1400-1417, a group of masters from the Faculty of arts repeatedly disputed topics taken from the De causis. Theorems I on divine immediacy, $\mathrm{IV}(\mathrm{v})$ on the ontological status of the first created being and XII(XIII) on the reflexive knowledge of intellect seem to have interested them most. At the University of Prague, at least seven questions examine the theorem I of the Liber de causis with striking similarities. Previously I mentioned the similarities between the question from the manual of Simon of Tišnov and a question from the manual of Mathias of Knin. There are also thematic similarities between the questions debated in the quodlibets from Prague and those from Erfurt, such as the topic of the knowledge of the intelligences from the Book of Causes IV(v). The question formulated by John Arsen (Prague, ca. 1400) (Utrum omnis intelligentia secunda intelligat se et alia) is taken up in identical form in the quodlibet of Mathias of Knin (Prague, 1409), which we read also in the Anonymous of Erfurt (Utrum quelibet intelligentia intelligat se et quamlibet aliam a se)..$^{27}$

Through the recurrence of topics and the presence of the same masters during successive years of quodlibetal disputations, the philosophical community of the university of Prague gradually forged a local tradition that enabled both the elaboration of specific positions and their transfer to other institutions, such as the Faculty of arts at the university of Erfurt. Moreover, the repetition of questions posed in these quodlibets, both from Prague and Erfurt, should not be interpreted as a lack of originality or as mere institutional imitation, but as a precious indicator of the scholarly networks of that time.

It is worth noting that the act of selecting theorems from the Liber de causis proves that the text was known, studied and open for several kinds of interpretation. It had already given rise to a rich exegetical tradition in which authors freely appealed to earlier arguments, like those used in various debates about the Eucharist. The presence of this tradition in such notorious academic events is notable, since ceremonies de quolibet played an essential role in the intellectual life of the university and could also stand as an echo of contemporary insti-

27 On this, see my thesis for École nationale des chartes, "Les disputes de quolibet dans les universités d'Europe centrale (fin du XIVe-début du Xve siècle). Étude de cas: les controverses eucharistiques et le rôle du Liber de causis, 2018. 
tutional and political torments. It suffice to recall that the above-mentioned questions analysing the first theorem of the Liber de causis in relation with the possibility of a philosophical explication of transubstantiation emerged against the background of tensions related to the efforts of Jan Hus and his followers to redefine the doctrine of the Eucharist. ${ }^{28}$ The quodlibetarii who defended his ideas, such as Mathias of Knin (1409) and Simon of Tišnov (1414), and those who rejected them, like Procopius of Kladruby (1417), approached the subject directly, using the vocabulary of the Liber de causis and its exegetical tradition. Yet explicit references to the Liber de causis also appear in other contexts. Indeed, the final disputation de quolibet in Prague took place in 1417 and was organised by Procopius of Kladruby, a devout Catholic. According to the studies of Kejř, ${ }^{29}$ during this disputation, a question touching on the problem of the causality of first and secondary causes was posed to the master Simon of Tišnov, at that time still a Hussite: Utrum prima causa agens ad extra cum causa secunda libere et contingenter sit aliquo termino terminata in potencia sua activa. Procopius himself debated a similar question at the beginning of the ceremony, during his questio principalis: Utrum primum principium rerum naturalium possit aliquem effectum absque secundo principio concurrente producere et de novo productum in esse perpetuo tempore naturaliter conservare. Simon of Tišnov also attributes three questions to three masters concerning the theme of the causality of the primary cause sine secundaria (one of which is edited here in the appendix). It is of the utmost importance to edit and analyse these questions in order to determine the role of the Book of Causes, and its exegetical tradition, in the philosophical and theological debates of central European universities before the Reformation.

28 The moderate Hussites, precursors of the Utraquist Church that was declared to be legitimate in 1433 at the Council of Basel, as well as the so-called "taborite" Hussites, who radicalised the ideas of reform, reflected on the problem of the real presence of Christ in the Eucharist, but the two factions did not agree on this problem. Cf. Cook 1973, p. 335349 .

29 Kejř, 1971, p. 158, p. 162. 


\section{Appendix 1}

Quodlibetical questions from the University of Prague inspired by and commenting upon the Liber de causis

Quodlibet organised by John Arsen of Langenfeld (140o? $)^{30}$

Utrum omnis intelligentia secunda intelligat se et alia. [= Liber de causis XII(XIII), 109-112]

Utrum causa prima agendo cum causa secunda ad extra agat libere contingenter. [= Liber de causis I, 1]

\section{Quodlibet organised by Mathias of Knin (1409) ${ }^{31}$}

Utrum prima causa vicem cuiuscumque cause secunde suplere poterit in causando. [= Liber de causis $\mathrm{I}, \mathrm{1}]$

Utrum intelligentie motrices orbium se et omnia citra se intelligant cognitione. [= Liber de causis XII(XIII), 109-112]

Utrum secunde cause possunt suos effectus causare prima causa non concausante. [= Liber de causis $\mathrm{I}, 1]$

Utrum inter omnia entia universi tantum primum ens sit ens summe simplex. [= Liber de causis IV, 37]

Utrum omnis intelligentia secunda intelligat se et alia. [= Liber de causis XII(XIII), 109-112]

Utrum omnis actio primi entis sit primum ens. [= Liber de causis IV, 37]

Quodlibet organised by Simon of Tišnov $(1416)^{32}$

Utrum sicut una secundarum causarum potest effectum causare prima causa ipsum non concausante, ita prima causa non cuiuslibet cause secunde vicem supplere potest in causando. [= Liber de causis $\mathrm{I}, 1]$

30 The manual of Jean Arsen of Langenfeld is preserved in Ms Leipzig, Universitätsbibliothek UB 1435, f. $188^{\mathrm{r}}-267^{\mathrm{r}}$. Cf. Šmahel 2007, p. 354-358. It is edited and discussed in I. Székely, "Pratiques intellectuelles à l'Université de Prague au xve siècle. Notes sur un Quodlibet de Jan Arsen de Langenfeld (c. 1400)", in Przegląd Tomistyczny, t. XXIV (2018), p. 227254 .

31 The manual of Mathias of Knin is to be found in ms Praha, Knihovna Metropolitni Kapituly, L 45, f. 1 ${ }^{\mathrm{v}}-15^{1}$. Cf. Kejř, 1971, p. 116-136.

32 The manual of Simon de Tišnov is in the same ms Praha as the manual of Jan Hus: MS Praha, Knihovna Národního muzea V C 42, f. $55^{\mathrm{r}}-146^{\mathrm{v}}$. Cf. Kejř 1971, p. 149-158. 
Quodlibet organised by Procope of Kladruby $(1417)^{33}$

Utrum primum principium rerum naturalium possit aliquem effectum absque secundo principio concurrente producere et de novo productum in esse perpetuo tempore naturaliter conservare. [= Liber de causis $\mathrm{I}, 1]$

Utrum inter intelligentias orbium universi secundum sub et supra essentialiter ordinatas superiores influant formas rerum fixiores. [= Liber de causis IV, 49]

Utrum intelligentie orbium superiores influunt formas rerum fixiores. [= Liber de causis $\mathrm{IV}, 49]$

Utrum causa secundaria agens in virtute primi agentis habeat in se virtutem illius mansivam [= Liber de causis $\mathrm{I}, 1]$

Quodlibetical questions from the University of Erfurt inspired by and commenting upon the Liber de causis

Quodlibet organised by Henry of Geismar $(1414)^{34}$

Utrum omnis causa primaria plus influat super effectum suum quam secundaria. [= Liber de causis $\mathrm{I}, 1]$

Quodlibet of 1417 (unknown quodlibetarius) ${ }^{35}$

Utrum quelibet intelligentia citra primam plena formis existens suam essentiam intelligat et substantias materiales. [= Liber de causis $\mathrm{Ix}(\mathrm{x}), 92$ and XII(XIII), 109-112] [disputed by Pierre Steinbecke]

Quodlibet from the beginning of the $15^{\text {th }}$ century (unknown quodlibetarius $)^{36}$

Utrum quelibet intelligentia intelligat se et quamlibet aliam a se. [= Liber de causis XII(XIII), 109-112]

33 The manual of Procope de Kladuby is in Ms Praha, Knihovna Metropolitni Kapituly, L 27, f. $3^{\mathrm{r}}-119^{\mathrm{r}}$. Cf. Kejř 1971, p. 158-169.

34 MS Erfurt, Universitäts- und Forschungsbibliothek Erfurt/Gotha, CA $4^{\circ} 236$, f. $29^{\mathrm{r}}-33^{\mathrm{v}}$.

35 Ms Erfurt, Universitäts- und Forschungsbibliothek Erfurt/Gotha, CA $4^{\circ} 236$, f. $47^{\mathrm{v}}-49^{\mathrm{r}}$.

36 Ms Erfurt, Universitäts- und Forschungsbibliothek Erfurt/Gotha, CA $4^{\circ} 236$, f. $35^{\mathrm{r}}-36^{\mathrm{v}}$. 


\section{Appendix 2: A quodlibetical question on the Liber de causis in the manual of Simon of Tišnov (ms Praha, Knihovna Národního muzea, $\mathrm{VC}_{42}, \mathrm{f}_{\mathrm{10}} \mathrm{1}^{\mathrm{r}}-103^{\mathrm{v}}$ )}

$102^{\mathrm{r}}$

Utrum sicud nulla secundarum causarum potest effectum creare prima causa ipsum non concausante, ita prima causa non cuiuslibet cause secunde vicem supplere potest in causando.

Quod questio sit falsa arguitur sic. Prima causa est omnino totaliter per se sufficientissima in causando quemcumque effectum; ergo vicem cuiuscumque cause secunde potest supplere in causando. Consequentia tenet, quia oppositum consequentis repugnat antecedenti. Et maior probatur, quia si prima causa non esset omnino et totaliter per se sufficientissima in causando quemcumque effectum, tunc incomplete, partialiter et diminute causaret effectus. Sed hoc est falsum; ergo etc.

In oppositum arguitur sic: prima causa nullius cause materialis vel subiective vicem potest supplere in causando; ergo questio vera. Maior probatur, quia causare materialiter vel subiective non potest competere prime cause; ergo etc. Maior probatur, quia si causare materialiter vel subiective competeret prime cause, tunc prima causa subducta materia vel subiecto materiatum causaret vel subiectatum; et sic prima causa esset materia vel subiectum, quod est inconveniens, quia tunc prima causa posset esse ignea, calida et quomodolibet informata et esset in potentia prius quam in actu, quod non potest sibi competere; ergo etc.

Contra illum qui concedat suppositum questionis, scilicet quod 'nulla secundarum causarum potest effectum causare' etc,

Contra: secunde cause non sunt essentialiter subordinate ad primam causam; ergo in causando suos effectus non dependent ordine essentiali a prima causa, et per consequens possunt suos effectus causare prima causa non concausante. Maior probatur, quia prima causa potest causare sine causis secundis, cum hoc dicat auctor Libri de causis: quidquid potest causa prima cum causa secunda vel cum causis secundis potest se sola ${ }^{37}$ ergo secunde cause non sunt essentialiter subordinate prime cause; ergo etc.

Item, pono quod prima causa subtrahat suam virtutem concausandi a causis secundis et conservet eas in esse dimittendo eas suis naturis et virtutibus causandi propriis, quo stante; tunc secunde cause causarent suos effectus prima causa non concausante. Ergo suppositum questionis falsum. 
Consequentia est nota. Et antecedens est positum ut possibile, eo quod prima causa [libere] talia libere facit etc.

Item, voluntas creata est causa secunda et producit effectum in se simpliciter malum; et qui nullo modo potest bene fieri, ut odire Deum vel suum proximum vel etiam periurium, quos effectus prima causa non potest concausare; ergo etc. Consequentia est nota. Prima pars antecedentis patet. Secunda pars antecedentis probatur, quia prima causa non potest concausare odium sui et sic de aliis; igitur etc.

Confirmatur: voluntas creata est causa secunda; et illa a se, ex se et per se libere contradictorie potest producere actum malum moraliter prima causa non concausante; ergo etc. Consequentia tenet. Et maior probatur, quia si prima causa actum malum moraliter concausaret, tunc ipsa esset causa mali moralis; et sic ab optimo bono posset procedere effectus malus moraliter.

Confirmatur iterum: si prima causa concausaret malum moraliter, tunc voluntas creata non a se originative, et ex se inchoative et per se completive libere contradictorie produceret actum moraliter malum, sed foret mota, ymmo necessitate a causa superiori, et sic foret excusabilis a peccato et sic de omni peccante.

Item, si suppositum questionis esset verum, sequitur tunc quod nulla causa secunda posset esse per se causa alicuius effectus. Consequens falsum et contra II Phisicorum ubi dicitur quod quedam sunt cause per se et quedam per accidens; ${ }^{38}$ et ibidem dicitur quod domificator per se edificat. ${ }^{39} \mathrm{Et}$ consequentia tenet, quia una causa secunda se sola et ex sui natura potest producere aliquem effectum, eo quod prima causa semper concausat.

Confirmatur: ymmo sequitur quod nulla foret operatio propria alicuius cause secunde, quod est falsum et contra Commentatorem IX Metaphysice dicentem unumquodque entium utitur actione sibi propria..$^{40} \mathrm{Et}$ ibidem dicit: qui ponunt unum agens esse quod agit omnia ${ }^{41}$ et tollunt a rebus suas proprias actiones non habent cerebrum aptum natum ad bonum..$^{42}$ Et consequentia patet, quia quelibet operatio, cum dependet a prima causa, prime cause est attribuenda; ergo non erit proprie propria secunde cause etc. Item, sequitur quod animalia non moverentur ex se et per se. Consequens contra

\footnotetext{
38 Cf. Aristoteles, Physica, II, 3, 195a25-195bio.

39 Aristoteles, Physica, II, 3, 195b20 (AL VII 1.2, p. 62, l. 8).

40 Averroes, Super Metaphysicam, IX, comm. 7, p. 38.

41 Averroes, Super Metaphysicam, IX, comm. 7, p. 38.

42 Sigerus de Brabantia, Quaestiones super Librum de causis, q. 2, p. 40, l. 28-29.
} 
Philosophum viII Physicorum. ${ }^{43}$ Et consequentia tenet, quia primo moverentur a prima causa et sic ab alio; et per consequens non ex se et per se etc.

Contra concedentem principale $\langle\mathrm{m}\rangle$ quesitum, puta quod 'prima causa non cuiuslibet cause secunde vicem' etc.

Contra: prima causa est simpliciter infinite virtutis in causando quemcumque effectum ad extra; igitur potest sine adiutorio cuiuscumque cause secunde causare quemcumque ad extra; et per consequens vicem cuiuscumque cause secunde implere potest in causando.

Confirmatur theologice: prima causa est causa simpliciter omnipotens et $103^{\mathrm{r}}$ mirabilissima in causando quemcumque effectum ad extra; | igitur ex sua potentia et mirabilissima causantia vicem cuiuslibet cause secunde supplere poterit in causando saltem mirabiliter et miraculose. Hoc enim non videtur aliquod impossibile vel contradictionem implicare.

Item, prima causa sine omni secunda causa produxit multos effectus in mundi principio per creationem; ergo prima causa et nunc vicem potest supplere in causando cuiuslibet secunde cause. Consequentia tenet, quia non minoris potentie est nunc quam erat in mundi principio etc.

Item, si causa prima vicem cuiuslibet cause secunde supplere non posset in causando, sequitur quod prima causa indigeret secundis causis ad causandum suos effectus. Sed hoc videtur falsum, quia tunc prima causa a se, ex se et per se non foret sufficientissima causa cuiuscumque effectus dati vel dabilis.

Item, prima causa est simpliciter prima causa perfectissima in ordine omnium causarum. Ergo primo et perfectissime quemcumque effectum causat sine concausantia cuiuscumque cause secunde cum ex hoc potissime dicitur prima causa simpliciter et perfectissima pro illo. Ergo priori supplet vicem cuiuslibet cause secunde in causando.

Item, prima causa est agens intellectuale libere contradictorie. Pone igitur quod in causando velit suspendere causationem cuiuscumque cause secunde, cum sua voluntas sit efficacissima, cui nihil poterit resistere. Sequitur quod cuiuscumque cause secunde supplere poterit in causando etc.

1 quia primo iter. $\mathrm{P}$

43 Aristoteles, Physica, VIII, 4, 254b (AL VII 1.2, p. 291, l. 14). 
Contra illum qui negat suppositum questionis, puta illud quia 'nulla secundarum' etc., arguitur quod cause secunde non possunt causare suos effectus prima causa non concausante etc.

Contra: secunde cause non possunt causare suos effectus prima causa non concausante; ergo etc. Consequentia nota est. Antecedens probatur, quia quidquid est causa cause est causa causati, ut dicit auctor Libri de causis. ${ }^{44}$ Sed prima causa est causa cuiuslibet secunde cause, ergo cuiuslibet ipsius effectus. Similiter maior probatur per primam propositionem Libri de causis que dicit quod omnis causa primaria plus est influens super suum causatum quam secunda causa universalis; ${ }^{45}$ igitur antecedens verum.

Item, cause secunde non habent esse nisi a prima causa, ergo nec habent causationem seu causalitatem prima causa non concausante; ergo non possunt causare suos effectus prima causa non concausante etc.

Item, dicit auctor Libri de causis quod prima causa regit omnes res preter hoc quod commisceatur eis, ${ }^{46}$ sed non posset omnes res regere nisi primo causaret quamlibet earum. Alias non esset prima omnium causa; ergo etc. Item, si non etc., sequitur quod prima causa non foret primum efficiens omnium aliorum et primum regens sapientissimum omnium aliorum et primum conservans sapientissimum singulorum causatorum principalius concurrens ad quemcumque effectum quam quemcumque causa secunda universalis aut particularis. Sed hoc est falsum; ergo etc.

Item, impossibile est esse effectum cuiuscumque cause secunde nisi talis effectus pro mensura sua a prima causa conservetur in esse et causaretur ab ea pro qualibet mensura sua in potissimo genere cause finalis, cum propter primam causam quilibet effectus universi principalissime intenditur et in esse producitur et conservatur; ergo etc.

Item, non potest esse effectus nec potest in esse primarie pro aliqua mensura nisi pro eadem mensura. Prima causa secundum ipsius ydealem rationem exemplariter format ipsum ad extra in existentia conservando; ergo etc. Consequentia tenet. Nam taliter prima causa dicitur rebus causatis suam causalitatem et bonitatem influere, quia secundum factibilitates earum exemplariter format eas ad extra in existentia conservando etc.

Item, maior est unio et concathenatio cause prime cum causis secundis quam inter primam et maximam rotam horologii et alias rotas minores; sed

24 sua] durandum (?) add. $\mathrm{P}$

$44 \quad$ Liber de causis, I, 10, p. 47, l. 28.

45 Liber de causis, I, 1, p. 46, 1. 1-2.

$46 \quad$ Liber de causis, $\mathrm{XIX}(\mathrm{xx}), 155$, p. 89, 1. 97-98. 
prima rota maxima causat motum omnium sequentium rotarum in horologio, cum cessante motu ipsius, cessat aliarum rotarum. Ergo, similiter, cessante causatione prime cause, cessant secundarum causarum causationes; ergo etc.

Item, tunc prima causa non foret causa universalissima, quia ad aliquem effectum eius se causalitas non extenderet, quod est falsum.

Item, melius est primam causam quemlibet effectum causare quam non causare quemlibet; ergo hoc erit sibi potius attribuendum si dicitur quod malitiam moralem non causat. Contra: prima causa conservat malitiam; ergo causat malitiam. Consequentia tenet, quia arguitur ab eodem ad idem, 10 quia in prima causa idem sunt conservatio et causatio etc.

Item, omne bonum prima causa vult; sed malitia moralis est bonum, quia verum; ergo bonum etc. Illud est bonum cuius finis est bonus, sed malitie finis est bonus; ergo malitia est bona. Minor patet, quia iusta vindicta est finis malitie et multa alia bona et decor et pulcritudo et perfectio universi.

Item, malitia est ordinata, quia minime ad penam; ergo est bona. Item, est ordinata in suo genere vel in sua specie; ergo est bona. Consequentia tenet: omne ordinatum est bonum.

Contra negantem principalem quesitum, quia 'prima causa non cuiuslibet cause secunde' etc.

Contra: nullam formam materialem nec aliquod accidens materiale prima causa potest per se sine concausantia substantie materialis producere; ergo 'prima causa non cuiuslibet cause secunde vicem' etc. Antecedens probatur, quia si sic, tunc forma materialis foret immaterialis, quia sine materia, et sic prima causa posset producere meum motum sine hoc quod ego movear ipsum subiective causando. Similiter posset disputationem vel causalitatem meam sine hoc quod ego subiective causer eam; sed illa sunt inconvenientia; ergo etc.

Item, de accidente spirituali conformiter arguitur; nam prima causa non potest actum volendi vel intelligendi creature producere nisi ipsa creatura concurrat cum eo, nedum subiective causando, sed etiam coagendo; ergo $\langle$ etc. $\rangle$.

Item, prima causa nullius agentis alterius vicem potest supplere in agendo virtute; ergo $\langle$ etc. $\rangle$. Consequentia patet. Maior probatur, quia si sic, tunc prima causa posset ad extra virtute generare; et sic genitum ad extra foret

2 cessat] cassat $\mathrm{P} \quad 2-3$ cessante] causante $\mathrm{P} \quad 17$ tenet] est bona add. sed del. 26 causando] causer eam sed illa sunt inconvenientia ergo etc. add. sed exp. $\mathrm{P} \quad 30$ actum] cactum $P$ 
Deus, quia esset eiusdem nature cum Deo; et ita homo, asinus, capra et sic de aliis possent esse prima causa sive Deus, quod est impossibile; ergo etc.

Item, nullius secunde cause formalis et intrinsece prima causa potest vicem supplere in causando formaliter; ergo 〈etc.〉. Maior, quia si sic, tunc illius effectus prima causa esset forma intrinseca et componibilis; et sic prima causa commisceretur effectibus et non esset omnino simplex, quod est impossibile. Ymmo foret intrinseca quidditas causatorum predicabilis de causatis; et sic ignis posset fore Deus, lapis similiter et sic de aliis. Que sunt impossibilia.

Item, prima causa non potest supplere vicem cause finalis quo alias prima 10 causa ordinaretur in se ipsam tamquam in finem gratia cuius, quod est inconveniens. Sed consequentia probatur ex hoc cum semper finis quo ordinatur in finem gratia cuius etc.

Item, tunc posset efficere compositum naturale sine materia et sine forma, quod est contra rationem compositi naturalis.

Item, prima causa non potest supplere vicem alicuius etc.; ergo etc. Maior, quia si sic, tunc inferioritatis varia conditio posset prime cause competere, quod est contra rationem eius cum sit dignissima et dives per se in omnes, ut vult auctor Libri de causis ${ }^{47}$ etc.

18 dignissima] vignissima $\mathrm{P}$

$47 \quad$ Liber de causis, $\mathrm{xx}(\mathrm{xxI}), 162, \mathrm{p} .92, \mathrm{l} .48$. 


\section{Bibliography}

\section{Manuscripts}

Erfurt, Universitäts- und Forschungsbibliothek Erfurt/Gotha, CA $4{ }^{\circ} 236$

Leipzig, Universitätsbibliothek, U B 1435

Praha, Knihovna Metropolitni Kapituly, L 27

Praha, Knihovna Metropolitni Kapituly, L 45

Praha, Knihovna Narodniho muzea, V C 42

\section{Primary Sources}

Aristotle, Physica, in Aristoteles latinus VII, 1.2, ed. F. Bossier et J. Brams, Leiden / New York, Brill, 199 .

Averroes, In Aristotelis Librum IX $(\Theta)$ Metaphysicorum Commentarius, comm. 7, in B. Bürke, Das neunte Buch $(\Theta)$ der lateinischen großen Metaphysik-Kommentars von Averroes. Text-Edition und Vergleich mit Albert dem Großen und Thomas von Aquin, Bern, Francke, 1969 .

Henry of Geismar - Calma, D., Székely, I. (2016), "Cause and Causality in Henry of Geismar's Questio de quolibet", in Calma 2016-2, p. 181-223.

Siger of Brabant, Les Quaestiones super Librum de causis, ed. A. Marlasca, Louvain / Paris, Publications universitaires / Béatrice-Nauwelaerts, 1972.

Monumenta historica Universitatis Carolo-Ferdinandeae Pragensis. Liber decanorum facultatis philosophicae Universitatis Pragensis ab anno Christi ${ }_{3} 67$ usque ad annum 1585, I, Pars 1 (1830-1832), Pragae, Joan. Nep. Gerzabek.

\section{Secondary Sources}

Calma, D. (ed.) (2016-1) Neoplatonism in the Middle Ages. Vol. 1. New Commentaries on Liber de causis (ca.1250-1350), Turnhout, Brepols.

Calma, D. (ed.) (2016-2), Neoplatonism in the Middle Ages. Vol. 2. New Commentaries on Liber de causis and Elementatio theologica (ca. 1350-1500), Turnhout, Brepols.

Calma, D. (2016a), "The Exegetical Tradition of Medieval Neoplatonism. Considerations on a Recently Discovered Corpus of Texts", in Calma 2016-1, p. 11-52.

Cook, W.R. (1973), "John Wyclif and Hussite Theology 1415-1436", in Church History 42, p. $335^{-349 .}$

Glorieux, P. (1925), La littérature quodlibétique. De 126o à 1320, Belgique, Le Saulchoir Kain: Revue des sciences philosophiques et théologiques.

Glorieux, P. (1935), La littérature quodlibétique, Paris, Vrin.

Imbach, R. (1996a), "Notule sur le commentaire du Liber de causis", in Freiburger Zeitschrift für Philosophie und Theologie 43, p. 304-323.

Imbach, R. (1996b), "Le traité de l' eucharistie de Thomas d' Aquin et les averroïstes", in R. Imbach, Quodlibeta, Articles choisis, Freiburg, Universitätsverlag, p. 3०9-331. 
Kejř, J. (1971), Kvodlibetni disputace na Pražské univerzitě, Praha, Universita Karlova.

Kleineidam, E. (1981), Universitas Studii Erffordensis. Überblick über die Geschichte der Universität Erfurt, Leipzig, St. Benno-Verlag.

Marlasca, A. (ed.) (1972)—see Siger de Brabant, Quaestiones super Librum de causis

Šmahel, F. (2007), Die Prager Universität im Mittelalter. Gesammelte Aufsätze/ The Charles University in the Middle Ages. Selected studies, Leiden, Brill.

Spunar, P. (1997), "La faculté des arts dans les Universités de l'Europe Centrale", dans L. Holtz et $\mathrm{O}$. Weijers (eds), L'enseignement des disciplines à la Faculté des arts (Paris et Oxford, XIII ${ }^{e}-X V^{e}$ siècles). Actes du colloque international de Paris, 18-20 mai 1995, Turnhout, Brepols, p. 467-475.

Weijers, O. (2009), Queritur utrum. Recherches sur la disputatio dans les universités médiévales, Turnhout, Brepols.

Weissenborn, H.J.C. (ed.) (1884), Acten der Erfurter Universität, Halle, Otto Hendel, vol. 2 .

Wippel, J.W. (1982), "The Quodlibetal Question as a Distinctive Litterary Genre", in Les genres littéraires dans les sources théologiques et philosophiques médiévales, Louvainla-Neuve, Institut d'Études Médiévales, p. 67-84. 